\title{
成人前期におけるキャリア環境変化対応性への影響要因 一生涯キャリア発達の視点に立って一
}

\author{
キャリアステージ研究所 堀 越 \\ Hiroshi HORIKOSHI \\ (Career Stage Institute) \\ Mieko WATANABE \\ (University of Tsukuba)
}

筑波大学 渡辺三枝子

A Model for Predicting Career Adaptability of Early Adulthood

- from the Viewpoint of Life-Span Career Development -

\begin{abstract}
The purpose of this research was to formulate and evaluate a model of behavioral and attitudinal variables for predicting career adaptability which is assumed as a major developmental task for early adulthood workers.

A multistage path model proposed a priori was constructed using the following eight variables. The six exogenous variables were awareness on own responsibility, intimacy, establishment of own aspiration, generativity, awareness on social role, and openness. The two intermediate variables were clarity of self-image, and empowerment.

The participants of this research were one hundred and forty male workers in their early 30s who are employees of a Japanese company.

Career adaptability was found to be explainable by some behavioral and attitudinal variables. Major findings are as follows: (1) Openness was the most influential variable on career adaptability. (2) Clarity of self-image, empowerment, and awareness of own responsibility were influential variables on career adaptability. (3) Such variables as establishment of own aspiration, intimacy, and awareness on social role have indirect effects on career adaptability through clarity of self-image and/or empowerment.
\end{abstract}

Keywords: career adaptabilirty; self-image; empowerment; developmental task; openness.

\section{I. 目 的}

\section{1. 研究の背景}

日本企業を取り卷く経営環境は，IT革新をはじめグロ 一バル競争, 少子高齢化などの影響を受け大きく変化し ており，企業は自社の優位性をあげるために，この環境 変化へ迅速に対応することを求められている。一方，こ の変化は社員のキャリア形成の考え方にも大きな影響を 与えている。従来, 多くの企業の雇用管理では, 社員が 会社側の要求に従っていれば終身雇用を保障しており, 社員は自らのキャリア形成を考える必要性に迫られなか ったといえる。しかしながら, 経営環境の著しい変化は, 終身雇用に拘らない企業の増加を促し（厚生労働省， 2002），エンプロイアビリティ（企業内外を問わず雇用
されうる能力）重視の雇用管理への転換を推し進めてい るといえる。この結果, 社員のキャリア形成は, 会社主 導ではなく自己責任で行う必要性がある，との認識が急 速に高まっている（労働政策研究・研修機構，2004）。 このような状況下で，今後とも社員が充実した職業生活 を送るためには，雇用環境の变化をはじめとする，社員 のキャリア形成に影響を及ぼす様々な社内外の環境変化 に対して，一人ひとりが主体的に取り組むことが求めら れているといえる。

キャリア発達の理論家(Super, 1988 ; Savickas, 1997) は, 成人期以降のキャリア発達において, 青年期までの キャリア成熟(career maturity)とは異なる「career adaptability」という概念を導入し，成人が環境変化に 対応することの重要性を提起している。Super(1988)は, 
「青年期までは, 意思決定などの能力は発達しつづける ものであり, 発達段階によって必要な能力は異なり, 各 段階にて多様な能力が育つので，キャリア成熟という概 念は適切である」と述べている。しかしながら彼は，成 人期以降において，これら能力は伸長するものではない こと, また成人期以降の課題に対処するのに必要な能力 は，その発達段階によって異なるものではなく課題によ って異なるものである，という観点からcareer adaptabilityという概念を提唱している。すなわち成人 期には，青年期までに獲得した能力と態度を応用し，環 境変化への積極的な対応行動をとることが求められると いえる。またSavickas(1997)は, career adaptabilityを 「仕事上の役割に就くというような予測できる課題に対 処するレディネスと仕事や仕事の状況の変化によって適 応を余儀なくされる予測できない変化へ対処するレディ ネス」と定義し, 個人と環境との相互作用を強調し, 自 らが変化することによって，より適切な状況を作り出す という積極的な意味合いも含むものであると主張してい る。このようにcareer adaptabilityは成人期のキャリア 発達において重要な概念であるが，この構造を明らかに するための研究は，十分に行われているとは言えない状 況である。

日本でのcareer adaptabilityに関連する先行研究とし て, 中央職業能力開発協会(2001)は, 職業人を対象に行 った調査において，キャリア形成を促進するためには， 個人が環境変化へ主体的に対応しようとする意識と行動 が重要な要因であるとする結果を提示している。キャリ ア発達の研究を行っている平野(1999)は, 企業の中間管 理職が, 自ら経験してきたキャリアを回顧・意味づけし， 将来に向けてキャリア発達の方向と可能性を展望する過 程を調査した結果，会社が提供するキャリア・パスの多 様性と社員個人のキャリア志向性が適合することによっ て,キャリア発達が促進されるということを示した。ま た堀越(2005)は，中年期におけるcareer adaptabilityの研 究をとおして, 環境変化への対応に影響を及ぼす要因を 明らかにしこれら要因によるcareer adaptabilityの構 造を提示した。この中で, (1)心的活力である「エンパワ 一メント」がcareer adaptabilityに対して最も影響を及 ぼている, (2)Schein(1978)が提唱した「自己イメージ の明確さ」は，「エンパワーメント」を介してcareer adaptabilityに間接的な影響を与えている，(3)中年期の 発達課題である「夢の現実吟味」および「世代性」が, career adaptabilityにとって重要な要因である，などの 知見が得られた。

本研究は, 堀越(2005)の40歳代, 50歳代を対象とした 中年期のcareer adaptabilityの研究を更にすすめ, 成人
前期 1)にあたる30歳代の職業人を対象として, 環境変 化への対応行動に影響を及ぼす要因を明らかにすること によって, 成人前期のcareer adaptabilityの構造を解明 する手掛かりを得ることを目的とした。なお，本研究で はcareer adaptabilityの日本語訳を中央職業能力開発協 会（2001）の先行研究に準拠し「キャリア環境变化対応 性」とした。

今後，企業における雇用管理がエンプロイアビリティ 重視になることを前述したが，これに伴い，職業人は自 らの専門性を今まで以上に強化することを求められる。 そして，この専門性をいろいろな場面（現在勤務してい る職場だけでなく, 場合によっては出向・転職・独立後 の新たな職場）で発揮するためにも，また変化していく 社内外の環境の中で主体的に職業生活を送るためにも, 「キャリア環境変化対応性」は職業人にとって基本的な 行動特性の一つであると考えられる。この意味において， 「キャリア環境変化対応性」はエンプロイアビリティを 促進する一つの要因として位置づけることができ, 今後, 労働市場の流動化が予測される中で，この分野の実証的 な研究を積み重ねる意義は大きいと思われる。

\section{2. 仮説モデルの構築}

本研究では, キャリア発達理論に基づいて, 成人前期 のキャリア発達に関連すると仮定される課題 (変数)を 抽出し，それらを用いてアプリオリにキャリア環境変化 対応性の仮説モデルを構築することとした。この仮説モ デルの根拠としたキャリア発達理論の視点は, 以下のと おりである。スーパー(1969)は, キャリア発達のプロセ スを「個人の認知と行動を規定する自己概念の発達と受 容, 探索と現実吟味, 自己概念の実現へと順次進展する 過程」であると提唱している。そして各個人が希望する 職業や具体的に選択する職業とは，その人がもっている 自己概念を職業という言葉に置き換えたものであると指 摘している。すなわち職業の選択と適応が可能になるた めには, 自己概念の発達が必要であるといえる。 Schein(1978)は, キャリア中期 2) において, 職業をどこ まで専門化するかの決定基準として, 自己イメージの要

1) 成人前期の年齢範囲は, Levinson(1978)の発達段階 説によると，概ね20歳代から30歳代である。Levinson は, 成人前期の中でも「30歳の過渡期」に大きな心理 社会的な変化に直面すると指摘しており, 本研究では この過渡期に相当する30歳代前半を対象とした。

2 ) Scheinの提唱するキャリアサイクルにおいて, キャ リア中期は25歳以降を指しており, 成人前期と概ね同 じ年齢段階といえる。 
素である動機・才能・価值を評価する必要性があると指 摘している。SuperとScheinのキャリア発達理論に基づ き，自己イメージ3）を明確にすることを1番目の視点と した。Hall(2002)は環境変化に対応するためには，個人 の能力面だけでなく適応モチベーション(adaptive motivation)という動機づけの側面が重要であると述べて いる。この動機づけの概念を包含し, さらに周囲に対し て積極的に働きかける心的活力としてのエンパワーメン ト(Spreitzer, 1996)を2番目の視点とした。キャリア発達 理論の基礎となった生涯発達心理学によると, 各発達段 階には解決することが期待されている心理社会的な発達 課題(developmental task)があるとされている。この発達 課題への対処が適切に行われれば，後に続く発達段階で 更に発達を続けることになる(Levinson,1978)。もし成人 前期の社員が環境変化に対応できないとするならば，職
業人 · 家庭人として期待されている発達課題に対して, 十分に取り組めていないことが予想される。この成人前 期における発達課題への取り組みが3番目の視点である。 環境変化に対応できるかどうかは性格特性によって影響 を受けると考えられる。パーソナリティ理論のBig Five の性格特性のうち, 特にキャリア発達に関係していると 思われる開放性(openness)を4番目の視点にあげた。日本 企業では自律的人材の必要性が叫ばれ，キャリア形成が 会社主導から個人主導に変わりつつあり, キャリアに対 する自己責任がますます求められている(渡辺,2001)。こ のような労働環境の変化に向き合ううえで, 自己責任の 自覚が，どの程度影響しているかを分析することは重要 であると考え5番目の視点とした。

本研究では, 以上の視点に基づいて図 1に示す仮説モ デルを構築し，以下に示す仮説を検証することとした。

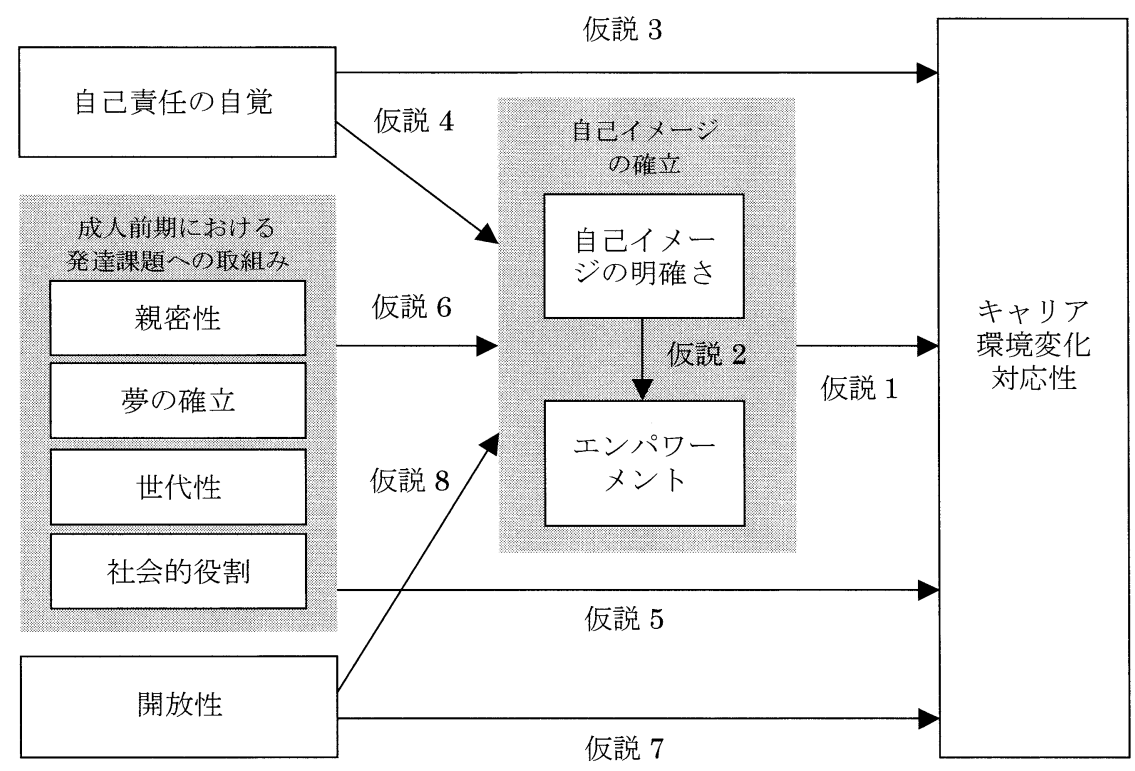

図1 仮説モデル

〈仮説 $1 〉 「$ 自己イメージの明確さ，およびエンパワー メントはキャリア環境変化対応性に正の影響を及ほ す」

〈仮説 $2 〉 「$ 自己イメージの明確さは，エンパワーメン トに対して正の影響を及ぼす」

仕事の経験を積むことにより職業上の自己イメージは 明確になっていく（Schein,1978）。自己イメージとは,

3) Superが用いる自己概念は, Scheinの自己イメージ と同義である。本研究では, 自己イメージという表現 を使用する。
自分は何が得意なのか, 何をやりたいのか, 仕事のどの ような側面に価值を置くのか, といった自らが認識して いる自分のイメージである。またSpreitzer(1996)によっ て研究された概念であるエンパワーメントは，仕事に意 義を見出し, 有能感をもち, 自律的に仕事を進めていく, そして自分の行動が職場に影響を与えていると実感する ことにより高まる心的活力のことである。将来の自己イ メージをもち, 現実の仕事の中でエンパワーメントを実 感する経験を積めるのなら, その相互作用により自己イ メージは次第に確立されていき, キャリアを取り巻く環 境変化への対応性は高まると考えられる。また, 自己イ 
メージが明確になれば，自らのキャリア実現に向け前向 きに取り組みエンパワーメントは高まると考えられる。 〈仮説3〉「キャリア形成に対する自己責任の自覚は, キャリア環境变化対応性に正の影響を及ぼす」

〈仮説4〉「キャリア形成に対する自己責任の自覚は, 自己イメージの確立に正の影響を及ほす」

キャリア形成に対する自己責任の自覚とは，会社や周 囲に依存するのではなく，自律的にキャリア形成を行お うとする意思であると捉えることができる。この自覚が 希薄だと環境变化についていけず，日常に流され自分を 見失うリスクが生じる。そして，自分は今後何を目指す のか，といった自己イメージの確立ができなくなってし まうと考えられる。

〈仮説5〉「成人前期における発達課題への取組みは, キャリア環境変化対応性に正の影響を及ぼす」

〈仮説 6 〉成人前期にお污る発達課題への取組みは, 自己イメージの確立に正の影響を及ぼす」

本研究で用いる成人前期に打ける発達課題は, Erikson(1950), Levinson(1978), Schein(1978), Super(1980)の理論に基づき，「親密性」「夢の確立」「世 代性」「社会的役割」の4つ4) とした。この発達課題は, 職場や家庭, 地域社会など周囲の人々と関わることによ り, 成人として社会から達成することが期待されている ものである。この課題に取り組む諸経験をとおして, 社 会に関わることへの重要性を認識し, 環境変化への対応 性も高まるものと考えられる。また，周囲の人々からの 様々な言動や評価などのフィードバックによって, 自己 イメージは影響を受け変化し, 次第に確立していくもの と思われる。

〈仮説7〉「開放性は，キャリア環境変化対応性に正の 影響を及ぼす」

〈仮説8〉「開放性は，自己イメージの確立に正の影響 を及ぼす」

将来の動向が読めない不確実な時代においては, 変化 しつづける状況に臨機応変に対応し, 柔軟に物事を考え 幅広く興味関心をもって行動することによって, 先が見 えるようになることは経験的にいえる。このような「開 放性」の特徵は環境変化に対応する上での影響要因と考 えられる。また, 開放性には進歩的で想像力や洞察力に 優れているという特性がある。これらは自己イメージを 確立するうえで正の影響があると思われる。

4 ）成人前期の発達課題として, Levinson(1978)は「職 業に就く」ことをあげているが, 本研究の対象者は全 員就業者のため,これを除外した。

\section{II. 方 法}

\section{1. 対象者}

まず対象企業としてA社を選定した。A社は日本を代 表する製造販売会社であり, 競争力強化と将来の成長を 目指し経営改革を進めており, 社員は社内外の大きな環 境変化に直面している状況下にある。この意味において， $\mathrm{A}$ 社は, キャリア環境变化対応性への影響要因を明らか にする本研究の趣旨に適している企業といえる。

そして，A社に勤務する30歳代前半の男性社員339名 に対して，2004年6月，郵便調査法により質問紙を配布 し，151名から回答を得た（有効回収率44.5\%)。そのう ち久損值のある回答を省いた 140 名を対象者とした。な お回答は無記名で行われた。年齢構成は, 30歳 $49.7 \%$, 31歳 $43.7 \%, 32$ 歳6.6\%であった。また職種は, 営業7.9\%, サービスエンジニア・システムエンジニア $19.9 \%$, 研 究・開発43.7\%, 生産・製造11.9\%, スタッフ $16.6 \%$ て った。

\section{2. 質問紙の構成}

質問紙は以下の 9 尺度, 82質問項目から構成されてい る。

（1）キャリア環境変化対応性

職業人生を主体的に送り意味あるものとするために は，環境変化を前向きに認識し積極的に変化への対応力 を身につける努力をすることが必要である。CADI (Challenge And Discovery Inventory: 中央職業能力開発 協会が開発した「環境変化自己診断ツール」）は，この ような視点に立ち, 職業人が職業人生のそれぞれの節目 で, 自己の変化対応力を点検し, 今後の課題を見つけて いくことを支援するために開発・標準化された成人向け の心理検查である。「キャリア環境変化対応性」は, CADIの質問項目である「実力主義の社会を実感する」, 「これからの社会がどうなっていくのか考えることがよ くある」,「新しい環境や状況に出会っても, 馴染んでい く自信がある」など27項目から構成されている。

\section{(2) エンパワーメント}

モチベーショナル概念としての「エンパワーメント」 の背景には, Bandura(1977)の自己効力感やDeci(1980)が 提唱した有能さと自己決定に基づく内発的動機づけが存 在している。Spreitzer(1996)は, さらに研究をすすめ, 「エンパワーメント」の構成要素として, 有意義感, 有 能感, 自己決定感, そしてインパクトの 4 つがあること を明らかにした。「エンパワーメント」の質問は平野 (1999)を参考にし，「今の仕事は私にとってやりがいがあ る」など有意義感に関する2項目、「これだけは誰にも負 
けないという仕事の領域を持っている」など有能感に関 する2項目,「仕事の課題や, やり方が決まっていても自 ら工夫し裁量の幅を広げている」など自己決定感に関す る2項目，「私の仕事は職場や会社に何らかの好影響を与 えていると実感できる」などインパクト関する 2 項目か らなる, 計8項目から構成されている。

\section{（3）自己イメージの明確さ}

キャリア・アンカーの概念を提唱したSchein(1978)は, 職業人は入社後, 様々な経験を経て次第に自己認識を深 め, より明確な職業上の自己イメージを確立していくこ とを発見した。彼の研究により，自己イメージには「自 覚された才能と能力」,「自覚された動機と欲求」,「自覚 された態度と価值」の3つの要素で構成されていること が明らかとなった。「自己イメージの明確さ」とは, キ ヤリアを形成するうえで, これらの要素についてどの程 度認識しているかである。金井(2002)は, これらの要素 を次の3つの問いかけとして内省することが，キャリア を考える基盤を提供すると指摘している。すなわち「自 分は何が得意か」,「自分はいったい何をやりたいのか」, 「どのようなことをやっている自分なら，意味を感じ， 社会に役立っていると実感できるか」である。「自己イ メージの明確さ」は, これらの問いをもとに作成され， さらに「自分はどのようなキャリアを目指すのか，はっ きりしている」を加えた項目から構成されている。

\section{（4）自己責任の自覚}

Superのキャリア発達理論を踏まえて開発された成人 キャリア成熟尺度（坂柳,1999）の一つである「自律性」 は，キャリア形成への取組みが自律的であるかどうかを 測定している。これは「自己責任の自覚」に関係してい るといえる。また, Rotter(1966)が提唱した Locus of control (統制の所在)の一つである Internal Control (内的 統制)は, 自らの成功や失敗などの出来事が, 運や他者 などの外的要因によってコントロールされているのでは なく, 自らの能力や努力といった内的要因によってコン トロールされているという信念であり，「自己責任の自 覚」に通じるといえる。これらを踏まえ, キャリア形成 に対する「自己責任の自覚」の質問は, 成人キャリア成 熟尺度抢よびLocus of controlを参考に作成された。「充 実した職業生活を送れるかどうかは, 自分の意志と責任 によると思う」，「自分のキャリアは会社や上司によって 決まると思う (逆転項目)」など8項目から構成されてい る。

\section{（5）夢の確立}

Levinson(1978)は，成人前期を人生において夢を確立 する重要な時期であるとし，「夢は児童期や青年期に端 を発しているが，明らかに成人特有の現象である」と主
張している。すなわち, 子供や青年時代に抱いていた夢 を, より現実的な夢として生活のなかに位置付けること が, 成人前期の重要な発達課題なのである。

「夢の確立」の質問は, Levinsonの理論に基づいて作 成され，「社会人としての経験を通じて，自分の夢が明 らかになってきている」，「仕事上の夢や希望はかなわな いものと諦めている (逆転項目)」など5項目から構成さ れている。

\section{（6）親密性}

Erikson(1950)は, 人間の生涯にわたる発達を乳児期か ら老年期にいたる8つの漸成的発達段階として表し，そ の段階にはそれぞれ固有の心理社会的危機が存在すると 捉えている。成人前期の段階には「親密 対 孤立」の 危機があり，これを克服し「親密性」を獲得することが， この段階の発達課題である。Eriksonによれば,「親密性」 とは自分を見失うことなく, 他人と親密な関係を確立す ることを意味する。一方，自分を器失するのではないか という不安にかられ, 親密な経験を回避すると, 周囲か ら孤立し深刻な孤独感に陥るという危機に直面してしま うといえる。「親密性」の質問はEriksonの概念に基づい て作成された。「人と親しくなるのが苦手である（逆転 項目)」,「私には何かあったら相談できる人がいる」, 「自分の意見を主張しても友人とは仲良くやっていける」 など6項目から構成されている。

\section{（7）世代性}

Erikson(1950)は，彼が提唱した漸成的原理において， 成人期の発達課題として「世代性」をあげている。「世 代性」とは次の世代を援助すること，すなわち自ら生産 的かつ創造的に仕事をし, 彼らを育て世話をすることで ある。Eriksonは, この漸成的原理の特徵として, 各々 の段階における発達課題が, それ以前㧍よび以降の全て の段階にも内在し梁く関連していると指摘している。し たがって, 成人前期の発達課題として「世代性」をあげ ることは，次に続く成人期に向けてのレディネスとして 意味あることと考えられる。またSchein(1978)は，キャ リア中期では, 他者の助言者になる準備を行うことが課 題であると主張しており，このことは「世代性」に合い 通じるものといえる。

「世代性」の質問はEriksonの概念に基づいて作成さ れ，「自分の経験や知識を部下や後輩のために役立てて いる」,「若い人たちが龍っていくのが楽しみである」な ど6項目から構成されている。

\section{（8）社会的役割}

Super(1980)は,「ライフ・キャリア・レインボー」モ デルを提唱し，キャリアを職業という役割だけでなく， 家庭や社会に扔ける役割の組合せという視点で捉えてい 
表1 各尺度の分析対象項目数, 平均, 標準偏差および信頼性

\begin{tabular}{lcccc}
\hline \multicolumn{1}{c}{ 尺度 } & 分析対象項目数 & $M$ & $S D$ & $\alpha$ 係数 \\
\hline キャリア環境変化対忘性 & 27 & 75.40 & 9.42 & .87 \\
エンパワーメント & 8 & 22.27 & 3.73 & .83 \\
自己イメージの明確さ & 4 & 10.23 & 2.13 & .77 \\
自己責任の自覚 & 6 & 16.74 & 2.46 & .62 \\
夢の確立 & 5 & 12.66 & 2.63 & .79 \\
親密性 & 4 & 11.49 & 2.31 & .74 \\
世代性 & 6 & 15.21 & 2.93 & .76 \\
社会的役割 & 5 & 15.46 & 2.01 & .56 \\
開放性 & 12 & 53.42 & 8.84 & .86 \\
\hline
\end{tabular}

る。人はそれぞれの発達段階において, 複数の役割を果 たすことを期待されているが, どの役割を重視するかは, その段階によって異なっており，また各人の人生観や価 值観によって決まるといえる。またSchein(1978)は，キ ヤリア中期では仕事上の役割だけでなく家庭での役割を 果たすことや自分自身の成長という課題に直面し，これ らを適切に調整する必要がある, と指摘している。「社 会的役割」の質問は, SuperとScheinの発達課題を踏ま え作成された。「職場では自分の役割を果たす自信があ る」,「私は仕事中心であり，家庭における役割はあまり 考えていない(逆転項目)」など6項目から構成されてい る。

\section{（9）開放性}

本研究では，パーソナリテイ理論であるBig Fiveモデ ルに基づいて和田(1996) ${ }^{5)}$ が開発した性格特性5因子測 定尺度の中の一つである「開放性」(Openness)を用いた。 この尺度は,「臨機応変な」「興味の広い」「進歩的」な ど12項目から構成されている。

な打回答方法は，「開放性」については，「まったくあ てはまらない」から「非常にあてはまる」までの7段階

5 ） 1980年代以降, 性格特性論の立場から人の基本的性 格特性は5次元で記述できるとするBig Five研究が欧 米で盛んに行われ，確固たる知見を蓄積してきている (堀, 2001)。日本では1990年代に入り Big Fiveの基礎 的研究がはじまり，日本文化に適したBig Five尺度の 標準化が進められてきている。このBig Five論を背景 として, 和田(1996)が開発した性格特性5因子測定尺度 は, 形容詞を用いて構成されて扔り，5因子構造を安 定的に抽出しやすく, 比較的少ない項目数で検査を実 施できる利点をもっている（堀, 2001）。
評定，「開放性」以外の質問については，「まったくあて はまらない」から「非常にあてはまる」までの4段階評 定である。

\section{3. 分析方法}

最初に, 尺度のCronbach $\alpha$ 係数を求めることにより 信頼性を確認し，その後の分析で用いる項目を決定した。 続いて, 先行研究およびキャリア発達理論に基づいて構 築した仮説モデル（図1）対して，9尺度を測定变数とし て扱い，構造方程式モデリングによる分析を行った。具 体的には，9つの測定変数のうち，「キャリア環境变化対 応性」,「エンパワーメント」,「自己イメージの明確さ」 を内生变数として, また「自己責任の自覚」,「夢の確立」, 「親密性」,「世代性」,「社会的役割」,「開放性」を外生 変数として以下の構造方程式を設定し, パス解析を実施 した。

構造方程式

$$
\begin{aligned}
\mathrm{x}_{1}= & \beta_{12} \mathrm{x}_{2}+\beta_{13} \mathrm{x}_{3}+\gamma_{14} \mathrm{x}_{4}+\gamma_{15} \mathrm{x}_{5}+\gamma_{16} \mathrm{x}_{6}+\gamma_{17} \mathrm{x}_{7} \\
& +\gamma_{18} \mathrm{x}_{8}+\gamma_{19} \mathrm{x}_{9}+\mathrm{e}_{1} \\
\mathrm{x}_{2}= & \beta_{23} \mathrm{x}_{3}+\gamma_{24} \mathrm{x}_{4}+\gamma_{25} \mathrm{x}_{5}+\gamma_{26} \mathrm{x}_{6}+\gamma_{27} \mathrm{x}_{7}+\gamma_{28} \mathrm{x}_{8} \\
& +\gamma_{29} \mathrm{x}_{9}+\mathrm{e}_{2} \\
\mathrm{x}_{3}= & \gamma_{34} \mathrm{x}_{4}+\gamma_{35} \mathrm{x}_{5}+\gamma_{36} \mathrm{x}_{6}+\gamma_{37} \mathrm{x}_{7}+\gamma_{38} \mathrm{x}_{8}+\gamma_{39} \mathrm{x}_{9} \\
& +\mathrm{e}_{3}
\end{aligned}
$$

内生変数 $\mathrm{x}_{1}$ : キャリア環境変化対応性

$\mathrm{x}_{2}:$ エンパワーメント

$\mathrm{x}_{3}$ : 自己イメージの明確さ

外生変数 $\mathrm{x}_{4}$ : 自己責任の自覚 $\mathrm{x}_{5}$ : 夢の確立

$\mathrm{x}_{6}$ : 親密性 $\quad \mathrm{x}_{7}$ : 世代性

$\mathrm{x}_{8}$ : 社会的役割 $\quad \mathrm{x}_{9}$ : 開放性 
表2 尺度間の相関係数

\begin{tabular}{|c|c|c|c|c|c|c|c|c|c|}
\hline 尺度 & 1. & 2. & 3. & 4. & 5. & 6. & 7. & 8. & 9. \\
\hline $\begin{array}{l}\text { 1. キャリア環境 } \\
\text { 変化対応性 }\end{array}$ & - & & & & & & & & \\
\hline $\begin{array}{l}\text { 2. エンパワー } \\
\text { メント }\end{array}$ & $.621^{* * *}$ & - & & & & & & & \\
\hline $\begin{array}{l}\text { 3. 自己イメージの } \\
\text { 明確さ }\end{array}$ & $.605^{* * *}$ & $.630^{* * *}$ & - & & & & & & \\
\hline $\begin{array}{l}\text { 4. 自己責任の } \\
\text { 自覚 }\end{array}$ & $.380^{* * *}$ & $.310^{* * *}$ & $.356^{* * *}$ & - & & & & & \\
\hline 5. 夢の確立 & $.537^{\star * *}$ & $.541^{* * *}$ & $.614^{* * *}$ & $.305^{* * *}$ & - & & & & \\
\hline 6. 親密性 & $.468^{* * *}$ & $.529 * * *$ & $.354^{* * *}$ & .125 & $.369^{* * *}$ & - & & & \\
\hline 7. 世代性 & $.452^{* * *}$ & $.411^{* * *}$ & $.262^{* *}$ & .079 & $.309^{* * *}$ & $.531^{* * *}$ & - & & \\
\hline 8. 社会的役割 & $.384^{* * *}$ & $.467^{* * *}$ & $.396^{* * *}$ & $.191^{*}$ & $.431^{* * *}$ & $.359^{* * *}$ & $.291^{* * *}$ & - & \\
\hline 9. 開放性 & $.645^{* * *}$ & $.449^{* * *}$ & $.455^{* * *}$ & $.183^{*}$ & $.537^{* * *}$ & $.339^{* * *}$ & $.422^{* * *}$ & $329^{\star * *}$ & - \\
\hline
\end{tabular}

表3 パス解析の中間結果

\begin{tabular}{l|ccc}
\hline 内生変数 & $\begin{array}{c}\text { 自己イメージの } \\
\text { 明確さ }\end{array}$ & $\begin{array}{c}\text { エンパワー } \\
\text { メント }\end{array}$ & $\begin{array}{c}\text { キャリア環境 } \\
\text { 変数 }\end{array}$ \\
\hline エンパ応性
\end{tabular}

Note. 表内の数値は構造変数から内生変数へのパス係数を示す ${ }^{*}: \mathrm{p}<.05 \quad * *$ : $p<.01 \quad * * *: p<.001$

$\beta_{\mathrm{ij}}$ : 内生変数 $\mathrm{x}_{\mathrm{j}}$ から内生変数 $\mathrm{x}_{\mathrm{i}}$ へのパス係数 $\gamma_{\mathrm{ij}}$ : 外生変数 $\mathrm{x}_{\mathrm{j}}$ から内生変数 $\mathrm{x}_{\mathrm{i}}$ へのパス係数 $\mathrm{e}_{\mathrm{i}}$ : 内生変数 $\mathrm{x}_{\mathrm{i}}$ の誤差変数

\section{III. 結 果}

\section{1. 尺度の信頼性分析および相関分析}

本研究で用いた9尺度のCronbach $\alpha$ 係数を求め信頼性 分析を行った。「自己責任の自覚」「親密性」「社会的役 割」の各尺度は, 質問項目を削除することによって信頼 性を上げた。信頼性分析の結果, 表1に示したように最
終的に9尺度，77項目となった。また，尺度間の相関分 析は表2に示す結果となった。

\section{2. 仮説の検証}

図1で示した「キャリア環境変化対応性」の仮説モデ ルに対して，構造方程式モデリングによるパス解析を行 った。標準パス係数は表3に示すとおりであった。この 標準パス係数のうち統計上有意となったパスのみを残 し，再度パス解析を行った結果，罒2に示す「キャリア 環境変化対応性への影響要因モデル」を得た。 

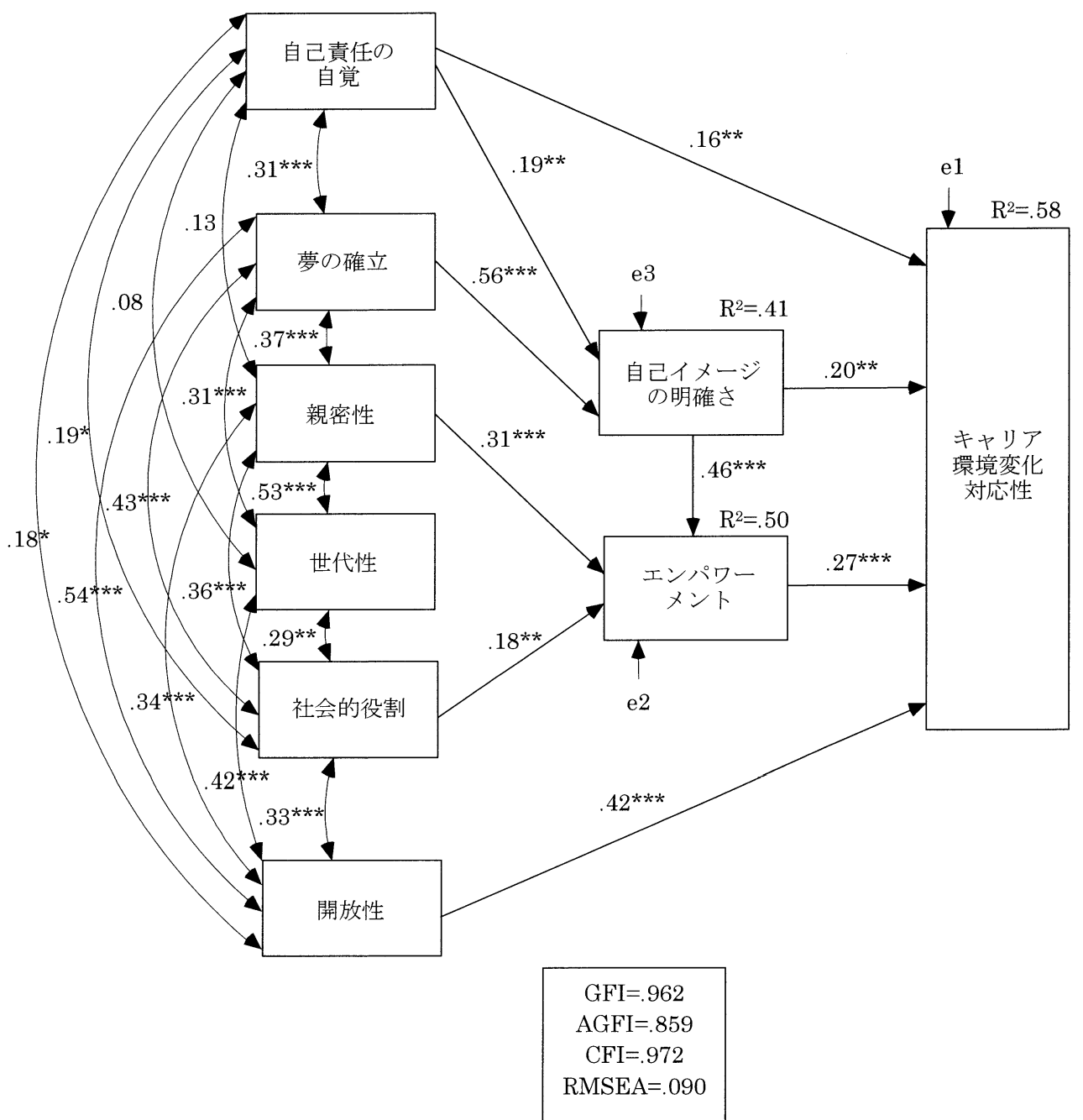

Note. $\quad *$ : $p<.05 \quad * *: p<.01 \quad * * *: p<.001$

$\mathrm{R}^{2}$ は決定係数を示す

図2キャリア環境变化対応性への影響要因モデル

このモデルの適合度に関しては， $\chi^{2}$ 值は $\chi^{2}=25.54$ $(\mathrm{p}<.05)$ で有意となり適合を示さなかったが， $\chi^{2}$ 検定 はサンプル数に影響を受けるため, 次の適合度指標を含 め総合的に判断する必要がある。まずGFI指標は一般的 に0.9以上が必要されて抢り(豊田, 1998), この影響要因 モデルはGFI=.962を示しており適合度は良いと言える。 またRMSEA指標は 0.05 以下が当てはまりがよく, 0.10 以 上が当てはまりが悪いと判断するため（豊田, 1998), こ の影響要因モデルのRMSEA =.090は, 当てはまりがよ いとは言えないまでも適合したモデルということができ る。

決定係数 $\left(\mathrm{R}^{2}\right)$ について見てみると,「キャリア環境変化

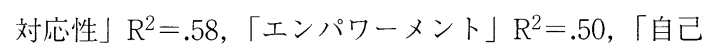
イメージの明確さ」 $\mathrm{R}^{2}=.41$ であり, このモデル内部の 構造変数は, 内生変数を説明するうえで意味ある変数と いえる。

この「キャリア環境変化対応性への影響要因モデル」 のパス・ダイアグラムに基づいて仮説の検証を以下のと おり行った。

〈仮説1〉「自己イメージの明確さ，およびエンパワー メントはキャリア環境変化対応性に正の影響を及ぼす」 については,「自己イメージの明確さ」(パス係数 $=.20$, $\mathrm{p}<.01)$ および「エンパワーメント」(パス係数 $=.27$, $\mathrm{p}<.001 ）$ が「キャリア環境変化対応性」へ有意な影響を 
及ぼしていたことから，仮説1は支持された。

〈仮説2〉「自己イメージの明確さは，エンパワーメン トに対して正の影響を及ぼす」については，有意な影響 （パス係数=.46, p<.001）が確認されたため，仮説 2 は支 持された。「自己イメージの明確さ」は，「エンパワーメ ント」を媒介として，「キャリア環境変化対応性」に間 接的な影響を与えており（間接効果: $.12=.46 \times .27 ）$, 総 合的な影響（総合効果）としては.32であった。

つまり自己イメージの明確さは, 環境変化に対応する うえでの影響要因であることが明らかとなった。また， 自己イメージが明確になることによりエンパワーメント が発揮され，その結果，環境変化に対応できるというこ とが判明した。

〈仮説3〉「キャリア形成に対する自己責任の自覚は, キャリア環境変化対応性に正の影響を及ぼす」について は，有意な影響（パス係数=.16, $\mathrm{p}<.01$ ）が確認された ため，仮説3は支持された。

〈仮説4〉「キャリア形成に対する自己責任の自覚は, 自己イメージの確立に正の影響を及ぼす」については， 「自己責任の自覚」が「自己イメージの明確さ」へ有意 な影響（パス係数=.19, p<.01）を及ほしていたため, 仮説4は支持された。また，この「自己責任の自覚」は， 「自己イメージの明確さ」と「エンパワーメント」を媒 介にして，わずかであるが間接的に「キャリア環境変化 対応性」に影響を及ぼしており（間接効果：.06=.19× $.20+.19 \times .46 \times .27)$, 直接的なパス係数 (.16) と合わ せた総合的な影響 (総合効果) としては.22であった。

つまり自己責任でキャリアを形成しようとする意思が あって, 自己イメージが明確になるとともに, 環境変化 にも対応できることが明らかとなった。

〈仮説 $5 〉 「$ 成人前期における発達課題への取組みは, キャリア環境変化対応性に正の影響を及ぼす」について は, どの発達課題も有意な影響が示されなかったため, 仮説5は支持されなかった。

〈仮説 6 〉成人前期における発達課題への取組みは, 自己イメージの確立に正の影響を及ぼす」については, 「夢の確立」（パス係数=.56 p<.001）が有意に「自己イ メージの明確さ」へ影響を及ぼしていた。また「親密性」 (パス係数=.31 $\mathrm{p}<.001$ ) と「社会的役割」（パス係数=.18 $\mathrm{p}<.01 ）$ が有意に「エンパワーメント」へ影響を及ぼし ていた。しかし，「世代性」は影響が示されなかった。 これにより，仮説6は部分的に支持された。また，発達 課題のうち「夢の確立」は,「エンパワーメント」およ び「自己イメージの明確さ」の両方を媒介にして，「キ ヤリア環境変化対応性」へ間接的な影響を及ぼしていた (間接効果: .182)。
つまり成人前期において発達課題に取り組むことは, 自己イメージを明確にしエンパワーメントを発揮するう えで影響を与えているが，環境変化への対応には間接的 な影響しか及ほしていないことが明らかとなった。

〈仮説7〉「開放性は，キャリア環境変化対応性に正の 影響を及ぼす」については，有意な影響（パス係数 $=.42, \mathrm{p}<.001 ）$ が確認されたため，仮説7は支持された。 なお「キャリア環境変化対応性」の影響要因のうち「開 放性」のパス係数が最も高いことが示された。

〈仮説8〉「開放性は，自己イメージの確立に正の影響 を及ぼす」については，有意な影響が示されなかったた め，仮説8は支持されなかった。

つまり開放性は, 環境変化に対応するうえで直接的な 影響要因であるが，自己イメージの確立に対しての影響 要因ではないことが判明した。

以上，仮説モデルに対してパス解析を行い検証した結 果，次のことが見いだされた。(1)「開放性」が「キャリ ア環境変化対応性」に，最も大きい直接的な影響を及ぼ している。(2)「自己責任の自覚」「自己イメージの明確 さ」「エンパワーメント」も「キャリア環境変化対応性」 に直接的な影響を与えている。(3)「自己イメージの明確 さ」に大きな影響を及ぼしているのは,「夢の確立」で ある。また「自己責任の自覚」も「自己イメージの明確 さ」に影響を与えている。(4)「エンパワーメント」に大 きな影響を及ぼしているのは，「自己イメージの明確さ」 と「親密性」である。また「社会的役割」も「エンパワ ーメント」に影響を与えている。(5)発達課題(「親密性」, 「夢の確立」,「社会的役割」) は, 直接,「キャリア環境 変化対応性」に影響を及ぼしているのではなく，「自己 イメージの明確さ」あるいは「エンパワーメント」を媒 介して影響を与えている。

また外生変数間のうち比較的高い相関関係に着目する と, 次のことが示唆された。(6)「世代性」が高まること によって，「親密性」が向上し「エンパワーメント」に 対して影響を与えている。(7)また「開放性」が高い人ほ ど「夢の確立」が促進され，「自己イメージの明確さ」 に影響を及ぼしている。

\section{IV. 考 察}

\section{1.「キャリア環境変化対応性」に最も影響を及 ぼしている「開放性」}

「キャリア環境変化対応性」とは, 職業人を取り巻く 環境変化への積極的な対応行動であり, Super(1988)が指 摘しているように成人期以降（すなわち成人前期や中年 期）も発達する概念である。したがって，「キャリア環 境変化対応性」は職業生活の中で直面する諸課題に対処 
するための能力として捉えることができ，多くの経験を 通じて獲得することができるといえる。一方，「開放性」 とは, 興味関心が広く進歩的であり, 想像性に富み, 臨 機応変さや機転の良さをもつパーソナリテイ特性であ る。キャリア発達の理論家であるHolland（1985）は, 「パーソナリティは発達的に形成され青年期までに決ま る」と指摘しているように, 「開放性」は成人期以降に おいては変化しづらい概念といえる。

この「開放性」は本研究で仮定したと扔り，「キャリ ア環境変化対応性」に影響を及ぼして掞り，最も大きな 影響要因でもあった。一方，「自己イメージの明確さ」 や「エンパワーメント」も「キャリア環境変化対応性」 に対して,「開放性」よりは小さいが影響を及ぼしてい た。この「自己イメージの明確さ」や「エンパワーメン ト」は積極的に仕事に取り組み多様な職業経験を通じて 生じるものである。

したがって30歳代の成人前期の職業人にとって,「キ ヤリア環境変化対応性」は, これら職業経験によって高 められる側面もあるが, それ以上に, 個人の根底にある 「開放性」のパーソナリティに依存していることが示さ れた。本研究の対象者である30歳代の人々にとって, こ れからパーソナリティを発達させるのは年齢段階からみ て難しいため (Holland, 1985), 現在, 開放性が低い個 人は今後とも環境変化に対応するのが困難になってしま うのであろうか。

しかしながら, 本研究で得た知見としては, この年齢 段階で発達させることが困難なパーソナリティに目を向 けるより, 職業経験によって発達の可能性のある自己イ メージやエンパワーメントに焦点をあてたほうが，環境 変化への対応性を発達させる上で, より実践的で効果的 であるということである。また, 発達課題(「親密性」, 「夢の確立」「社会的役割」）は「自己イメージの明確さ」 や「エンパワーメント」に影響を与えていることが明ら かとなったことから, 個人が自らの発達課題に主体的に 取り組み達成できるよう支援することが重要であり，こ れにより結果的に環境変化へ対応できるということが示 唆されたといえる。

また，パーソナリティの発達が可能な時期である幼少 期から青年期までの間に, 開放性を十分に発達させてお けば，次に続く成人前期や中年期に扔いて，個人が直面 する環境変化への対応のレディネスも向上するのではな いだろうか。すなわち青年期までの間に, 家庭や学校, 地域社会などの場で開放性を発達させる経験を積むこと が, 成人前期以降の環境変化へ対応するうえで重要であ ることが示唆されたといえる。

\section{2.「自己イメージの明確さ」と「エンパワーメ ント」の重要性}

「自己イメージの明確さ」は，「キャリア環境変化対 応性」に影響を与えていた。つまり，自己イメージが明 確になることによって, 周囲の環境に関心をもち, 環境 変化への対応性も高まるとことが示された。スーパー （1969）は, この自己イメージと対応性について, キャ リア発達の観点から次のように述べている。すなわち彼 は, 「キャリア発達とは, 自己イメージの発達プロセス, 具体的には自己イメージを模索し現実吟味を加え実現し ていく一連のプロセスである。またキャリア発達は, 職 業にかかわる選択行動や適応行動が発達することであ る」と提唱している。この意味に扔いて, 自己イメージ の明確さが, 職業や職場組織そして社会といった環境に 対応するうえでの影響要因であるということが本研究で 示されたことは，スーパーのキャリア発達理論を支持し たものといえるであろう。

また「自己イメージの明確さ」は「エンパワーメン ト」へ影響を及ぼしていた。このことは，自己イメージ が明確になることによってキャリアの方向性が次第に明 らかになり, 具体的なキャリア目標として設定されれば, 自己効力感が高まり (Bandura, 1997), 現実の仕事に対 してエンパワーメントが生じる，と解釈できる。

そして,「自己イメージの明確さ」によって影響を受 けた「エンパワーメント」は,「キャリア環境変化対応 性」に影響を及ぼしていることが明らかとなった。エン パワーメントの構成要素である有意義感が高まるという ことは, 職場組織や会社における自らの仕事の意味を強 く自覚することであり, また仕事を通じて周囲の人々や 顧客に貢献しているという実感を抱くことである。した がって, エンパワーメントが高まることによって, 組織 や社会といった自らを取り巻く環境を今まで以上に意識 し関心を抱くことになるといえる。またエンパワーメン 卜の要素である有能感が強まるということは, 仕事に対 する自信が深まり, 自らが経験したことのない課題に対 しても挑戦意識をもって取り組むことが可能となり, 結 果として予測できない不確実な環境変化に対しても対応 性は高まるものと考えられる。

\section{3. 自己イメージの確立に必要な発達課題}

成人前期に扔ける発達課題は,「キャリア環境変化対 応性」に直接, 影響を与えているのではなく,「自己イ メージの明確さ」や「エンパワーメント」を媒介して, 影響を及ぼしていることが明らかとなった。

まず，発達課題の一つである「夢の確立」が，「自己 イメージの明確さ」に対して影響を及ぼしていた。自分 
の夢をこの成人前期に確立し，実現していこうとする意 思や情熱によって，自己イメージが明確になり，今後の キャリアの方向性も次第に見えてくるものといえよう。 30歳代の職業人にとって, 現実の仕事だけに埋没するの ではなく，また夢ばかりを追うのでもなく，夢を抱きな がら現実の職業生活に主体的に取り組み，夢を実現する チャンスを掴んでいく，そのような態度と行動が極めて 重要であると思われる。

発達課題のうち，「親密性」および「社会的役割」が， 「エンパワーメント」へ影響を及ぼしていた。「親密性」 は，心理社会的な成長を促すために親密な人間関倸を築 くことである（Erikson, 1950）。したがって，職業生活 を歩むうえで様々な問題に直面した時に, 周囲に相談で きる親密な関係の上司, 先輩, 友人あるいはパートナー などがいるならば, 彼らから経験に基づく知恵や価值あ る情報の提供を受け，これらを現実の仕事に生かすこと によってエンパワーメントが高まるものと考えられる。

「社会的役割」については次のように解釈できる。成 人前期では，仕事が全てであるという人生観ではなく， 家庭における夫や父親の役割を重視し, 趣味や余㗇も人 生において大切であると認識している者ほど, 結果的に 仕事に対して生き生き取り組め，エンパワーメントも高 まるものと考えられる。このことは, Schein(1978)が指 摘している「家庭・自己・仕事の役割に目をむけ適切に バランスをとっていく」という成人前期の発達課題の重 要性を改めて立証したものといえるであろう。

\section{4.「自己責任の自覚」の影響}

「自己責任の自覚」は, Rotter(1966)が提唱する Internal controlの概念に依拠している。すなわち自らの 能力, 努力, 意思といった内的要因によって周囲の出来 事はコントロールされており, 他者や運などに責任転嫁 するのではなく，あくまで自己に責任があるという考え 方である。本研究では，この「自己責任の自覚」が「キ ヤリア環境变化対応性」に対して直接的に，また「自己 イメージの明確さ」を媒介して間接的に影響を及ぼして いた。

「自己イメージの明確さ」への影響に関しては, 次の ように解釈できる。すなわち，職業生活をただ受身的に 送るという姿勢ではなく，自己責任で主体的にキャリア 形成しようとする意思をもって仕事に取り組むことによ って, 自分にとっての仕事上の価值観や興味 ·関心, 強 みとしての能力が何であるかを職業経験が梁まるに伴い 次第に認識することができ, 自己イメージが明確になっ ていくものと考えられる。

また,「キャリア環境変化対応性」への影響について
は, 自己責任を強く自覚すると内的統制が高まり, 自ら を取り巻く環境に対して統制可能感を生じさせ, 結果と して環境变化への対応性を高めると解秎できる。成人前 期において, 職業人が組織や社会への適応行動を取れる ようになるには，キャリア形成を自己責任で主体的に行 うよう各個人へ啓発的に㗢きかけることや，一人ひとり の内的統制を高める経験を日常の仕事を通じて育成的に 行うことが求められるといえよう。

最後に本研究の限界点であるが，まずA社1社のみを 対象とした調查であり，日本の男性全般に沉化するのは 困難である。今後, 普遍的な研究とするためには複数企 業を調查対象に加える必要がある。また，9尺度の中の 「自己責任の自覚」,「社会的役割」の各尺度は, さらに 信頼性を高める質問項目を精選し, 改めてこれら要因の 影響について検討する必要がある。今後の課題としては, 「親密性」などの発達課題の概念を比較的少ない項目で 測定したが，これら概念の尺度開発をさらにすすめる必 要があると思われる。また成人前期のキャリア発達の研 究としては今回は男性のみであったが，女性を対象とし た同様の研究も合せて実施していく必要があろう。

\section{引用文献}

Bandura, A. 1977 Self-efficacy : Toward a unifying theory of behavioral change. Psychological Review, 84, 191-215.

Bandura, A. 1997 Self-efficacy : The exercise of control. New York: W.H. Freeman and Company.

Deci, E.L. 1980 The Psychology of Self-determination.

Lexington, Mass.: D.C.Health \& Company.

Erikson, E.H. 1950 The Childhood and Society.

W.W.Norton \& Company. (仁科弥生 訳幼児期 と社会1・2 みすず書房 1977, 1980)

Hall, D.T. 2002 Careers In and Out of Organizations.

Thousand Oaks, California: Sage Publications.

平野光俊 1999 キャリア・ドメイン 千倉書房.

Holland, J.L. 1985 Making Vocational choices.

Englewood Cliffs, Nj: Prentice-Hall. （渡辺三枝子.

松本純平・館暁夫 訳 職業選択の理論 雇用問題 研究会 1990)

堀洋道 2001 心理測定尺度集 I サイエンス社.

堀越弘 2005 中年期に扔けるキャリア環境変化対応性一

の影響要因. 産業・組織心理学研究, 18(2), 77-87.

金井壽宏 2002 働くひとのためのキャリア・デザイン PHP研究所.

中央職業能力開発協会 2001 キャリア・レコード等改善 研究委員会報告書 一ホワイトカラーの主体的キャ 
リア形成支援ツールの開発一 中央職業能力開発協 会.

厚生労働省 2002 平成 14 年度雇用管理調査 厚生労働省 大臣官房統計情報部.

Levinson, D.J. 1978 The seasons of a man's life. New York: Alfred A. Knopf. （南博訳 ライフサイクル の心理学 講談社 1980)

Mitchell, K.E., Levin, A.S., \& Krumboltz, J.D. 1999 Planned Happenstance. Journal of Counseling and Development, 77, 115-124.

労働政策研究・研修機構 2004 教育訓練とキャリア相 談. ビジネス・レーバー・トレンド, 10, 15-17.

Rotter, J.B. 1966 Generalized expectancies for internal versus external control of reinforcement. Psychological Monograph, 80, 1-28.

坂柳恒夫 1999 成人キャリア成熟尺度の信頼性と妥当性 の検討. 愛知教育大学研究報告, 48, 115-122.

Savickas, M.L. 1997 Career adaptability: an integrative construct for Life-span, Life-space theory. The Career Development, 45, 247-259.

Schein, E.H. 1978 Career Dynamics : Matching Individual and Organizational Needs. Reading, MA: Addison-Wesley. (二村敏子. 三善勝代 訳 キ ヤリアダイナミクス 白桃書房 1991)

Spreitzer, G.M. 1996 Social Structual Characteristics of Psychological Empowerment. Academy of Management Journal, 39, 483-504.

Super, D.E. 1980 A life-span, life-space approach to career development. Journal of Vocational Behavior, 13, 282-298.

Super, D.E., Thompson, A.S., \& Linderman, R.H. 1988 Adult Career Concerns Inventory: Manual for research and exploratory use in counseling. Palo Alto, CA: Consultant Psychologists Press.

スーパーD.E. 1969 職業的発達理論の研究 日本職業 指導協会.

高橋潔・金井壽宏 2002 経営学のイノベーション 一元 気の出る経営行動科学一. 一橋ビジネスレビュー, 50, 118-131.

豊田秀樹 1998 共分散構造分析（入門偏） 朝倉書房. 和田さゆり 1996 性格特性用語を用いたBig Five尺度の 作成. 心理学研究, 67,61-67.

渡辺三枝子 2001 生涯キャリア発達の理論, 渡辺三枝 子・渡邊忠・山本晴義（編）産業カウンセリングの 理論的な展開(pp.57-69) 至文堂.

(平成17年 3 月 9 日受稿, 平成18年 2 月 15 日受理)

\section{堀越弘 (Hiroshi HORIKOSHI)}

\section{略歴}

キャリアステージ研究所代表。筑波大学大学院教育研究 科カウンセリングコース修了。(株)富士ゼロックス総合教 育研究所にて, 人事研修, キャリアデザイン研修などに 従事した後, 独立。専門はキャリアカウンセリング, 人 材育成。

\section{主要論文・著書}

「中年期におけるキャリア環境変化対応性への影響要因」 (産業・組織心理学研究, Vol.18, 77-87, 2005年) 「オーガニゼーショナル・カウンセリング序説」

(分担執筆, ナカニシヤ出版, 2005年)

\section{渡辺三枝子 (Mieko WATANABE)}

\section{略歴}

筑波大学大学院人間総合科学研究科教授。米国ペンシル バニア州立大学大学院博士課程カウンセリング心理学 . カウンセラー教育専攻, 哲学博士号(Ph. D.)取得。

\section{主要論文・著書}

「オーガニゼーショナル・カウンセリング序説」

(編者, ナカニシヤ出版, 2005年)

「キャリアの心理学」(ナカニシヤ出版, 2003年)

「新版カウンセリング心理学」(ナカニシヤ出版, 2002年) 「キャリアカウンセリング入門」(ナカニシヤ出版, 2001年) 